\title{
Short communication: Investigation of extra-intestinal pathogenic Escherichia coli virulence genes, bacterial motility, and multidrug resistance pattern of strains isolated from dairy cows with different severity scores of clinical mastitis
}

\author{
Simony T. Guerra, ${ }^{1} \oplus$ Henrique Orsi, ${ }^{2} \oplus$ Sâmea F. Joaquim, ${ }^{1} \odot$ Felipe F. Guimarães, ${ }^{1} \oplus$ Bruna C. Lopes, ${ }^{1}$ \\ Felipe M. Dalanezi, ${ }^{1} \odot$ Domingos S. Leite, ${ }^{3} \odot$ Helio Langoni, ${ }^{1}$ Jose C. F. Pantoja, ${ }^{1} \odot$ Vera L. M. Rall, ${ }^{2} \odot$ \\ Rodrigo T. Hernandes, ${ }^{2} \odot$ Simone B. Lucheis, ${ }^{4}$ and Márcio G. Ribeiro ${ }^{1 *}$ \\ ${ }^{1}$ Department of Veterinary Hygiene and Public Health, School of Veterinary Medicine and Animal Sciences, Sao Paulo State University, Botucatu, \\ SP 18618 681, Brazil \\ ${ }^{2}$ Department of Microbiology and Immunology, Sao Paulo State University, Botucatu, SP 18618 689, Brazil \\ ${ }^{3}$ Department of Genetics, Evolution, Microbiology and Immunology, University of Campinas, SP 13083 970, Brazil \\ ${ }^{4}$ Paulista Agency of Agribusiness Technology, Bauru, SP 17030 000, Brazil
}

\begin{abstract}
Escherichia coli is a major pathogen involved in the etiology of environmentally derived bovine mastitis and is characterized by a variety of virulence factors (VF). Mammary infections with $E$. coli have shown a wide range of clinical signs, causing changes in milk (score 1, or mild), abnormal appearance of milk and udder inflammation (score 2, or moderate), and abnormalities in milk, udder inflammation, and systemic signs of illness (score 3, or severe). Nevertheless, to date, the profile of the genes related to the virulence of the pathogen in mammary infections and the severity scores of cases have not been thoroughly elucidated. Therefore, a panel of 18 virulence-encoding genes associated with extra-enteric pathogenicity of E. coli (ExPEC) were investigated in addition to in vitro swimming and swarming motility profiles and antimicrobial susceptibility/ resistance patterns among $114 \mathrm{E}$. coli strains isolated from cows with clinical mastitis and different severity scores. Of 114 clinical cases, 39.5, 54.4, and $6.1 \%$ were mild, moderate, and severe, respectively. The main genes related to VF harbored by isolates were adhesins (fimH 100\%; ecpA $64.0 \%$, fimA 31.6\%), serum resistance (traT 81.6\%; ompT 35.1\%), siderophores (irp2 9.6\%), and hemolysin (hlyA 7\%). Among the isolates studied, $99.1 \%$ showed in vitro resistance to bacitracin and cloxacillin, and $98.2 \%$ to lincosamin. Of the total isolates, $98.2 \%$ were considered multidrug resistant based on the multiple antimicrobial resistance index. No significant difference was observed between mean
\end{abstract}

Received August 20, 2019.

Accepted December 3, 2019.

*Corresponding author: marcio.ribeiro@unesp.br swimming $(13.8 \mathrm{~mm})$ and swarming $(13.5 \mathrm{~mm})$ motility, as well as severity scores of clinical mastitis and the ExPEC genes studied. The isolation of strains resistant to various antimicrobials, even though tested only in vitro, highlights the importance of rational use of antimicrobials for mastitis treatment. The high prevalence of the genes related to serum resistance ( $\operatorname{tra} T$ and $o m p T$ ) and adhesion (ecpA) of the pathogen, in addition to main associations between the genes fim $H$, ecp $A$, and traT among cows with severity scores of $1(15 \%)$ and 2 (22.6\%), indicates that the genes traT, ecpA, and ompT could be further studied as biomarkers of ExPEC for clinical intramammary infections. In addition, the ExPEC genes omp $T$ (protectin), ibe10 (invasin), and ecpA (adhesin) were investigated for the first time among cows with mastitis, where scores of clinical severity were assessed. Results of this study contribute to the characterization of virulence mechanisms and antimicrobial resistance profile of ExPEC variants that affect dairy cows with different scores of clinical mastitis.

Key words: environmental mastitis, extra-enteric pathogenicity of Escherichia coli, mechanism of virulence, multidrug resistance

\section{Short Communication}

Escherichia coli bacteria belong to the normal gut microbiota of humans and multihost animals and are widely found in the environment. The pathogen is opportunistic in nature, is characterized by a high diversity of virulence factors ( VF), and is a primary causal agent of enteric and extra-enteric signs in humans, livestock, wildlife, and companion animals (Bélanger et al., 2011; Croxen et al., 2013). Escherichia coli is the major enterobacterial species involved in the etiology of 
bovine clinical mastitis from an environmental origin. Escherichia coli-induced infections in the mammary gland of dairy cows exhibit a wide range of clinical signs causing changes in milk (mild, or score 1), abnormal appearance of milk and udder inflammation (moderate, or score 2), and additional systemic signs of illness (score 3, or severe; Wenz et al., 2001; Pinzón-Sánchez and Ruegg, 2011).

In the last several decades, studies that investigated the genes that harbor VF related to diarrheic or enteric infections among E. coli isolated from bovine mastitis have described a poor relationship (Kaipainen et al., 2002; Momtaz et al., 2012). To date, the specific profile of the genes that encode VF associated with clinical bovine mastitis, as well as the influence of these virulence properties on the severity scores of clinical infections, has not been determined (Leimbach et al., 2017). Hypothetically, other VF with cytotoxic effects on the cells, invasins or the ability to resist the immune response in the blood serum could be related to the extra-enteric pathogenicity of Escherichia coli (ExPEC) in mammary infections (Hogan and Smith, 2003; Fernandes et al., 2011). In this context, some studies have investigated the association between E. coli motility and clinical mastitis. Persistent cases were associated with swimming motility (Lippolis et al., 2014), whereas severe cases (score 3) were related to swarming motility (Guerra et al., 2019).

In addition, the increase of multidrug resistance of bacteria to conventional antimicrobials is an emergent issue worldwide (Marston et al., 2016), including the multidrug resistance of $E$. coli isolates from bovine mastitis (Suojala et al., 2011; Fairbrother et al., 2015).

Considering the effect of environmental mastitis caused by E. coli on dairy farms, the wide diversity of virulence properties of the pathogen, in addition to the incomplete knowledge regarding the profile of the genes that encode VF related to mammary infections and its influence on clinical severity of cases, the present study investigated the association between a panel of 18 ExPEC genes, antimicrobial resistance pattern, and bacterial motility from dairy cows with clinical mastitis presenting different severity scores.

This study was developed in accordance with the Ethics Committee on Animal Use (CEUA) guidelines and approved by the School of Veterinary Medicine and Animal Science (FMVZ), Sao Paulo State University (UNESP), Botucatu, Sao Paulo State, Brazil; protocol number 2015/19688-8.

Farms and herds were eligible for the study if they met the following criteria: (1) Holstein or Holstein cross-breed cows, (2) farms with at least 200 lactating cows, (3) average milk yield $>20 \mathrm{~kg} /$ cow/day, (4) bulk tank milk SCC $<400,000$ cells/mL, (5) farms that used milking machines, and (6) farms with available electronic heath and production records.

A convenience sample of $114 \mathrm{E}$. coli isolated from dairy cows with clinical mastitis was used. The animals belonged to 10 farms from Minas Gerais and Sao Paulo states from the central region of Brazil, where dairy farming is common. Milk samples were collected from all cows that experienced clinical mastitis from 2017 to 2018. Data regarding milk yield, DIM, and parity were recorded monthly.

The diagnosis of clinical mastitis and severity scores were defined as follows: mild (score 1) presented macroscopic changes in the milk appearance (e.g., presence of flakes, pus, and blood). Moderate cases (score 2) were characterized by abnormal appearance of milk and udder inflammation (swelling, pain or redness in the affected mammary gland), whereas cases with additional signs of inappetence, fever, tachycardia, tachypnea, decubitus, or ruminal hypomotility were classified as severe (score 3; Wenz et al., 2001; Pinzón-Sánchez and Ruegg, 2011). Before the study onset, milkers were trained to recognize the different severity scores of clinical mastitis.

Milk samples were collected at detection of clinical mastitis, before treatment, in sterile tubes after teat antisepsis with $70.0 \%$ alcohol. Samples were kept refrigerated $\left(4-8^{\circ} \mathrm{C}\right)$ until microbiological culturing. Approximately $10 \mu \mathrm{L}$ of each milk sample was streaked onto defibrinated sheep blood agar (5.0\%) and MacConkey agar (Oxoid, Basingstoke, UK). The plates were incubated at $37^{\circ} \mathrm{C}$ under aerobic conditions for $72 \mathrm{~h}$. Microorganisms were classified according to the National Mastitis Council (NMC, 1999). Colonies compatible with $E$. coli were identified based on conventional phenotypic tests, as follows: gas/glucose and sulfuric acid production, urea hydrolysis, L-tryptophan deamination, motility, indole production, lysine decaboxylation, and Simmons citrate (Farmer et al., 1985). Intramammary infection was defined as the presence of at least $3 \mathrm{cfu}$ of E. coli. Milk samples that yielded more than 3 different colony types were considered contaminated and were discarded (NMC, 1999).

A panel of 18 genes that encode adhesins (fimA, fimH, ecp A, papA, papC, afaBC, and sfaDE), toxins (hlyA, vat, cnf, and cdt), siderophores (iroN, irp2, and iucD), invasins (ibe10), and serum resistance (traT, kpsMTll, and ompT) were investigated.

Briefly, all the colonies were suspended in $200 \mu \mathrm{L}$ of sterile water. The suspensions were boiled for $10 \mathrm{~min}$ and frozen for $10 \mathrm{~min}$. Then, the suspensions were centrifuged at $10,000 \times g$ for $1 \mathrm{~min}$ (Centrifuge $5424 \mathrm{R}$, Eppendorf, Hamburg, Germany), and the supernatants were used for the PCR as the DNA template. The PCR was performed in a total volume of $12.5 \mu \mathrm{L}$ containing 
$5 \mathrm{~m} M$ reaction buffer, Tris- $\mathrm{HCl}(\mathrm{pH} 8.0), 25 \mathrm{~m} M \mathrm{KCl}$, $10.75 \mathrm{mM} \mathrm{MgCl} \mathrm{m}_{2}, 0.1 \mathrm{~m} M$ deoxynucleotide triphosphates, $5 \mathrm{p} M$ of each primer, $0.25 \mathrm{U}$ of Taq polymerase (Promega, Madison, WI), and $5 \mathrm{ng}$ of DNA. An amplification was performed in a thermocycler (GeneAmp PCR System 9700, Applied Biosystems, Foster City, $\mathrm{CA}$ ) with the following cycle conditions: initial heating at $95^{\circ} \mathrm{C}$ for 5 min followed by 25 cycles of denaturation at $95^{\circ} \mathrm{C}$ for $30 \mathrm{~s}$, annealing at variable temperatures based on the primer for $30 \mathrm{~s}$, and extension at $72^{\circ} \mathrm{C}$ for $1 \mathrm{~min}$. After the amplification of the fragments, the reactions were subjected to agarose gel electrophoresis $(1.0 \%)$. The images were recorded by an image capture system (Alphalmager 2200, Alpha Innotech, San Leandro, CA).

The classification of isolates into the different $E$. coli phylogroups was performed by using Quadruplex PCR, as previously described (Clermont et al., 2013).

For bacterial motility, samples were cultured on MacConkey agar at $37^{\circ} \mathrm{C}$ for $24 \mathrm{~h}$. Then, the colonies were suspended in tubes containing $3 \mathrm{~mL}$ of brain heart infusion broth (Oxoid), incubated in aerobic conditions, and kept overnight at $37^{\circ} \mathrm{C}$. Swarming $(0.5 \%)$ and swimming $(0.3 \%)$ motility tests were performed in agar plates according to previously described methods (Lippolis et al., 2014).

All isolates were subjected to in vitro antimicrobial susceptibility testing using the disc diffusion method, according to the Clinical Laboratory Standard Institute guidelines (CLSI, 2016). Ten different antimicrobial classes used on bovine mastitis treatment along lactation and dry cow therapy were tested: (1) cephalosporins (30 $\mu \mathrm{g}$ of ceftiofur, $30 \mu \mathrm{g}$ of cefoperazone), (2) tetracycline (30 $\mu \mathrm{g}$ of tetracycline), (3) fluoroquinolones (5 $\mu \mathrm{g}$ of enrofloxacin, $5 \mu \mathrm{g}$ of marbofloxacin), (4) aminoglycosides $(10 \mu \mathrm{g}$ of gentamicin, $30 \mu \mathrm{g}$ of neomycin, $10 \mu \mathrm{g}$ of streptomycin), (5) penicillin and aminopenicillins (10 $\mu \mathrm{g}$ of ampicillin, $10 \mu \mathrm{g}$ of amoxicillin, $25 \mu \mathrm{g}$ of cloxacillin), (6) sulfonamides (300 $\mu \mathrm{g}$ of sulfadiazine, $25 \mu \mathrm{g}$ of trimethoprim/sulfamethoxazole), (7) amphenicols (30 $\mu \mathrm{g}$ of florfenicol), (8) lincosamides (2 $\mu \mathrm{g}$ of lincomycin), and (9) polypeptides (10 IU of bacitracin), and (10) macrolides (15 $\mu \mathrm{g}$ of erythromycin).

Days in milk were categorized into 1 (0-99 d), 2 (100$199 \mathrm{~d})$, and 3 (>200 d), and the parity was categorized into 1,2 , or $\geq 3$ lactations. Frequency distributions were produced for the categorical variables (season, parity, clinical severity of cases, gene prevalence, phylogroups, and antimicrobial susceptibility).

The swimming and swarming motility variables were transformed to a logarithmic scale for data normalization and further analysis.

Mixed models (PROC MIXED, SAS Institute Inc., Cary, NC) were used to compare the mean swimming and swarming motility between different scores of clinical mastitis. The variables DIM and parity were initially included in the model but were not statistically significant. Farm was included in the model as a random effect to consider the clustering of strains within the same herd. Logistic regression models (PROC GLIMMIX, SAS Institute Inc.) were used to estimate the chances of identifying each studied gene among severity scores.

The chi-squared (or Fisher) tests were used to evaluate the association between antimicrobial susceptibility results (sensitive, partially sensitive, and resistant) and severity scores. Finally, mixed models (PROC MIXED, SAS Institute Inc.) were used to compare the mean swimming and swarming motility among the antimicrobial susceptibility results.

Herds had an average $( \pm \mathrm{SD})$ of $423 \pm 187$ lactating cows that produced, on average, $30.4 \pm 4.4 \mathrm{~kg}$ of milk $/ \mathrm{d}$. From 3,345 clinical mastitis cases diagnosed during the study period, E. coli was isolated from 160 (4.8\%) milk samples. Severity scores were available for 114 cases, of which $39.5(\mathrm{n}=45), 54.4(\mathrm{n}=62)$, and $6.1 \%(\mathrm{n}=7)$ were mild, moderate, and severe, respectively.

Days in milk at clinical mastitis was missing for 2 clinical cases. Most cases occurred within the first third of lactation $(48 / 112=42.8 \%)$, followed by the final third $(32 / 112=28.6 \%)$ and middle third $(32 / 112=$ $28.6 \%)$.

No difference $(P=0.428)$ was observed between the mean diameter of swimming $(13.8 \mathrm{~mm})$ and swarming $(13.5 \mathrm{~mm})$ areas of motility and severity scores of clinical mastitis.

Isolates were most susceptible to gentamicin $(114 / 114=100 \%)$, marbofloxacin $(113 / 114=99.1 \%)$, sulfamethoxazole/trimethoprim $(112 / 114=98.2 \%)$, ceftiofur $(110 / 114=96.5 \%)$, enrofloxacin $(108 / 114=$ $94.8 \%)$, and cefaperazone (107/93.9\%). In contrast, most isolates showed resistance to cloxacillin (113/114 $=99.1 \%)$, bacitracin $(113 / 114=99.1 \%)$, lincomycin $(112 / 114=98.2 \%)$, and erythromycin $(62 / 114=$ $54.4 \%)$. The multiple antimicrobial resistance index $(\geq 0.3)$ revealed that $98.2 \%$ of isolates $(112 / 114)$ were considered multidrug resistant. Among these isolates, $53.6 \%$ (60/112), $8.9 \%(10 / 112)$, and $6.2 \%(7 / 112)$ were resistant simultaneously to 4,5 , or $\geq 6$ groups of antimicrobials, respectively.

The detection of ExPEC-related gene results is summarized in Table 1. The predominant genes identified were adhesins (fimH, 114/114=100\%; ecp A, 73/114= $64.0 \%$; fim $A, 36 / 114=31.6 \%)$, serum resistance $(\operatorname{traT}$, $93 / 114=81.6 \%$; omp T, $40 / 114=35.1 \%)$, siderophores $($ irp2, $11 / 114=9.6 \%)$, and hemolysin $(h l y A, 8 / 114=$ $7 \%$ ). The main associations between the genes studied with clinical severity were fimH, ecpA and traT among 
Table 1. Absolute (no./total) and relative (\%) prevalence of extra-enteric pathogenicity of Escherichia coli gene detection in 114 Escherichia coli isolated from cows with clinical mastitis in Brazil from 2018-2019 ${ }^{1}$

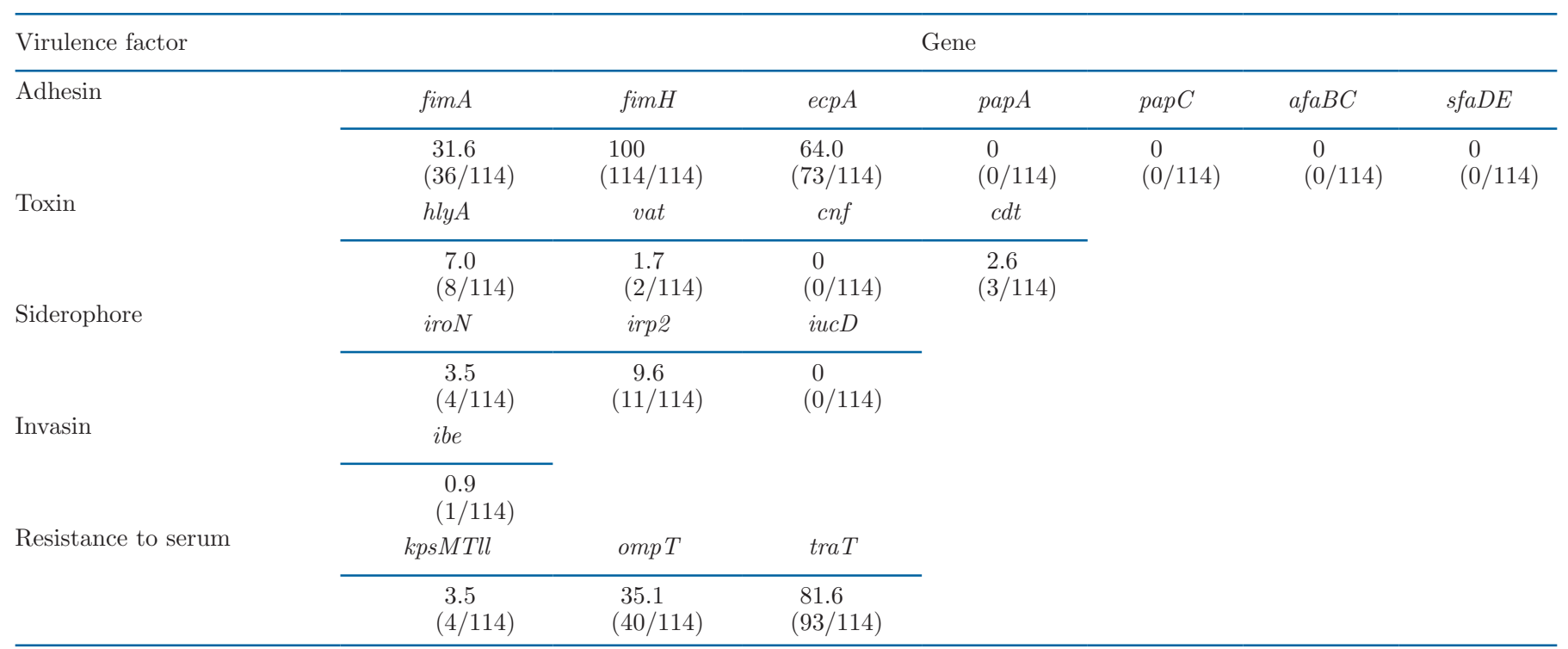

${ }^{1}$ fim $A=$ fimbriae; fim $H=$ fimbriae; $\operatorname{ecp} A=$ adhesin; $p a p A=\mathrm{P}$ fimbriae; $p a p C=\mathrm{P}$ fimbriae; afaBC = adhesin; $\operatorname{sfaDE}=$ fimbriae; $h l y A=$ hemolisin; vat = toxin; $c n f=$ cytotoxic necrosis factor; $c d t=$ toxin; $i r o n N=$ siderophore; $i r p 2=$ yersin bactin; iucD $=$ siderophore; $i b e 10=$ invasin; omp $T=$ invasin, $\operatorname{traT}=$ invasin; $k p s M T l l=$ type $l l$ capsule.

cows with severity scores of $1(7 / 45=15 \%)$ and 2 $(14 / 62=22.6 \%)$, whereas several combinations were observed (Table 2). No statistical association $(P>0.05$ for all tested genes) was observed between the detection of different ExPEC genes and severity scores of clinical cases.

Most of the isolates belonged to phylogroups B1 $(58 / 114=50.9 \%)$ and $\mathrm{A}(45 / 114=39.5 \%)$. Other phylogroups identified at low frequencies were $\mathrm{E}(7 / 114$ $=6.1 \%)$, B2 $(1 / 114=0.9 \%)$, and $\mathrm{C}(1 / 114=0.9 \%)$. One $(1 / 114=0.9 \%)$ isolate was not classified in any of the E. coli phylogroups with the method used and was referred to as unknown.

We identified high in vitro multidrug resistance to antimicrobials among the $114 \mathrm{E}$. coli isolated from dairy cows with different clinical severities of mastitis. The genes that encode adhesins ( im $H=100 \%$, ecp A $=64 \%$, fim $A=31.6 \%)$ and serum resistance $(\operatorname{traT}=$ $81.6 \%$, omp $T=35.1 \%$ ) were highly prevalent (Table 1 ). Besides no significant association between the aforementioned genes and the severity of clinical mastitis, the high prevalences of traT, ecpA, and ompT indicate that these genes could be further studied as biomarkers of clinical severity of bovine mastitis. The lack of association between the genes studied and severity scores may be due to insufficient statistical power, which may be a limitation of the present study. Nevertheless, to our knowledge, the ExPEC-associated genes related to serum resistance omp $T$, invasin $i b e 10$, and adhesin ecp $A$ were investigated for the first time in clinical cases that were scored for severity.

Of the 3,345 cows sampled during the study, 160 $(4.8 \%)$ E. coli were isolated. These results are consistent with similar studies in which the pathogen has been isolated among $8 \%$ of clinical cases in Canada (Olde Riekerink et al., 2008), 10\% in the United States (Pinzón-Sánchez and Ruegg, 2011), and 5.8\% in Brazil (Kobori et al., 2004), confirming the role of this enterobacterium on the etiology of environmental mastitis of dairy cows.

Most studies that focused on bovine mastitis by $E$. coli have reported a predominance of mild cases (score 1; Wenz et al., 2001; Momtaz, 2010; Pinzón-Sánchez and Ruegg, 2011).

Swimming and swarming motility of $E$. coli are determined by flagella, and these abilities of bacterial movement have been recently investigated in vitro as virulent properties (Lippolis et al., 2014). Swimming motility is determined by the individual movement of bacteria on the surface of the agar, as opposed to swarming, which is characterized by group migration (packs) of organisms (Partridge and Harshey, 2013). Recently, swarming motility was associated with severe cases (score 3) of clinical mastitis in dairy cows from Brazil (Guerra et al., 2019). Conversely, no statistical association $(P=0.428)$ was observed between the diameter of swimming and swarming areas of $E$. coli motility and the severity of the cases. The distributions 
of swimming and swarming motility at each severity score are shown in Figures 1 and 2. These data indicate that the influence of these types of $E$. coli motility on clinical mastitis severity remains unclear.

The greatest in vitro susceptibility of the isolates for antimicrobials (>90\%) studied was observed for gentamicin, marbofloxacin, sulfamethoxazole/trimethoprim, ceftiofur, enrofloxacin, and cefaperazone, indicating that sulfonamides and third-generation cephalosporins may be considered for the treatment of bovine mastitis by E. coli (Liu et al., 2014; Tomazi et al., 2018).

Most of the E. coli (>90\%) isolated from sampled cows showed resistance to cloxacillin, bacitracin, and lincomycin, with a wide variety of resistance profiles. In addition, the multiple antimicrobial resistance index $(\geq 0.3)$ revealed that $>90 \%$ of isolates were considered multidrug resistant, a finding that agrees with similar studies (Kobori et al., 2004; Srinivasan et al., 2007)

Table 2. Distribution of different gene profiles by clinical severity of Escherichia coli isolates from cows with clinical mastitis in Brazil from 2018-2019

\begin{tabular}{|c|c|c|c|}
\hline $\begin{array}{l}\text { Severity } \\
\text { score }\end{array}$ & Gene profile & $\mathrm{N}^{1}$ & $\begin{array}{c}\text { Frequency } \\
(\%)\end{array}$ \\
\hline $1(\mathrm{n}=45)$ & 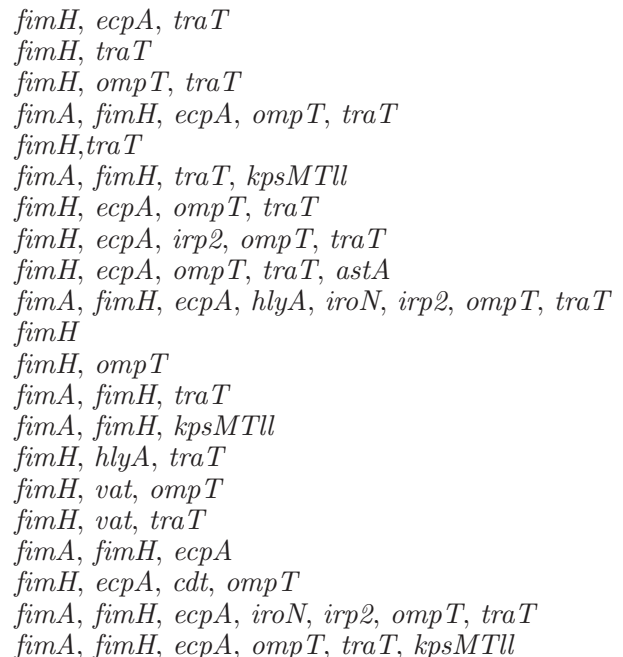 & $\begin{array}{r}11 \\
4 \\
3 \\
3 \\
2 \\
2 \\
2 \\
2 \\
2 \\
2 \\
1 \\
1 \\
1 \\
1 \\
1 \\
1 \\
1 \\
1 \\
1 \\
1 \\
1\end{array}$ & $\begin{array}{r}24.5 \\
8.9 \\
6.7 \\
6.7 \\
4.4 \\
4.4 \\
4.4 \\
4.4 \\
4.4 \\
4.4 \\
2.2 \\
2.2 \\
2.2 \\
2.2 \\
2.2 \\
2.2 \\
2.2 \\
2.2 \\
2.2 \\
2.2 \\
2.2\end{array}$ \\
\hline $2(\mathrm{n}=62)$ & 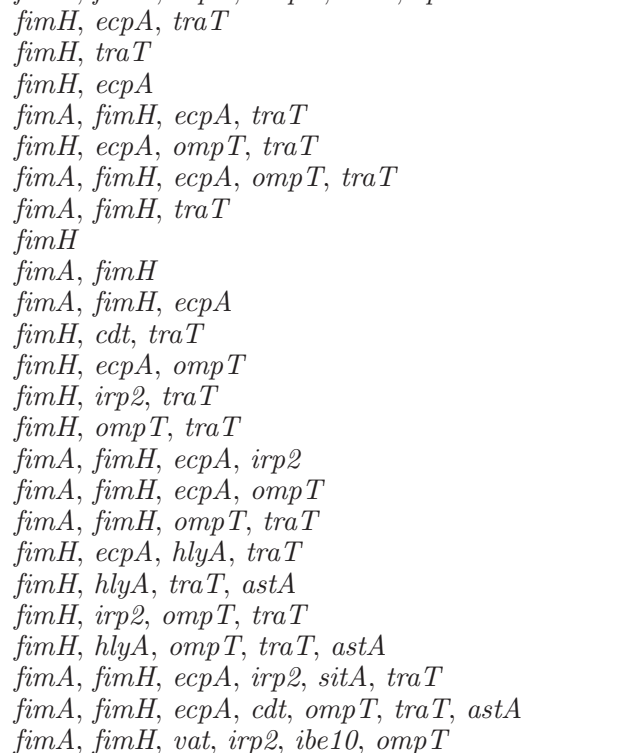 & $\begin{array}{r}14 \\
6 \\
5 \\
5 \\
5 \\
5 \\
3 \\
2 \\
2 \\
1 \\
1 \\
1 \\
1 \\
1 \\
1 \\
1 \\
1 \\
1 \\
1 \\
1 \\
1 \\
1 \\
1 \\
1\end{array}$ & $\begin{array}{r}22.6 \\
9.7 \\
8.1 \\
8.1 \\
8.1 \\
8.1 \\
4.8 \\
3.2 \\
3.2 \\
1.6 \\
1.6 \\
1.6 \\
1.6 \\
1.6 \\
1.6 \\
1.6 \\
1.6 \\
1.6 \\
1.6 \\
1.6 \\
1.6 \\
1.6 \\
1.6 \\
1.6\end{array}$ \\
\hline $3(\mathrm{n}=7)$ & $\begin{array}{l}\text { fimH, } \operatorname{tra} T \\
\text { fimH, ecp } A, \operatorname{tra} T \\
\text { fimA, fimH, traT } \\
\text { fimH, ecp } A, \text { omp } T, \operatorname{traT} \\
\text { fimH, ecpA, hlyA, sit } A, \text { traT }\end{array}$ & $\begin{array}{l}2 \\
2 \\
1 \\
1 \\
1\end{array}$ & $\begin{array}{l}28.6 \\
28.6 \\
14.3 \\
14.3 \\
14.3\end{array}$ \\
\hline
\end{tabular}

${ }^{1} \mathrm{~N}=$ number of isolates. 


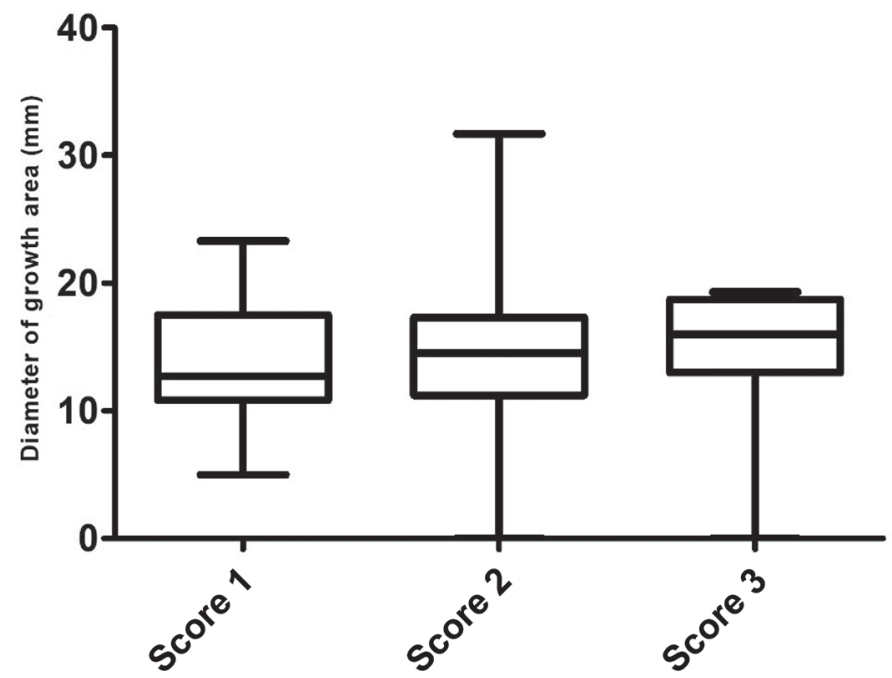

Figure 1. In vitro swimming motility for 114 Escherichia coli isolates from clinical cases of bovine mastitis. Clinical cases were classified as score 1 (changes only in milk appearance), score 2 (changes in milk and mammary gland inflammation), and score 3 (changes in milk, mammary gland inflammation, and systemic signs) in Brazil from 2018 to 2019. Bottom line of boxes $=$ first quartile; upper line $=$ third quartile; center line $=$ median .

and represents a public health issue, particularly in Brazil (Ribeiro et al., 2015). Brazil is the fifth largest milk producer in the world (up to 35 billion liters/year; IBGE, 2016). Bovine mastitis remains a major disease on dairy farms (Hogeveen et al., 2011), and more than 30 different antimicrobial agents are commercially available to treat mammary infections during lactation and at dry-off. Treatment of mammary infections

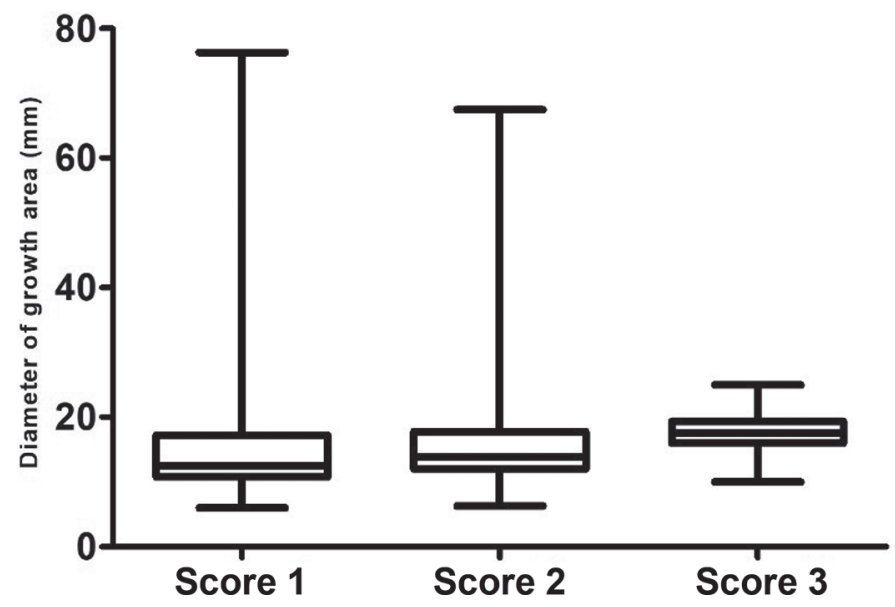

Figure 2. In vitro swarming motility for 114 Escherichia coli isolates from clinical cases of bovine mastitis. Clinical cases were classified as score 1 (changes only in milk appearance), score 2 (changes in milk and mammary gland inflammation), and score 3 (changes in milk, mammary gland inflammation, and systemic signs) in Brazil from 2018 to 2019. Bottom line of boxes $=$ first quartile; upper line $=$ third quartile; center line $=$ median . comprises over $80 \%$ of the use of antimicrobials in dairy farms, and dry cow therapy is the only procedure still allowed to use antimicrobial agents with a prophylactic recommendation for livestock species in most countries (Pol and Ruegg, 2007). In addition, studies suggest that antimicrobial therapy of nonsevere clinical cases caused by gram-negative pathogens is not necessary (Oliveira and Ruegg, 2014), since it does not improve outcomes such as SCC or milk production (Fuenzalida and Ruegg, 2019). These aforementioned factors, in addition to improper antimicrobial therapy of bovine mastitis, may increase the selective pressure to multidrug-resistant bacteria (Giguère et al., 2010), including by E. coli. In fact, the responsible use of antimicrobial therapy among domestic animals is an emergent problem in the One Health concept and should be targeted to conserve drugs critical to human therapy (Ribeiro et al., 2015).

The virulence of enteric and extra-enteric E. coli in humans, livestock, companion animals, and wildlife is characterized by a complexity of mechanisms, represented mainly by adherence of the pathogen to host cells, toxin production, iron uptake, and the ability to resist the serum immune response (Kaper et al., 2004). Unlike enteric infections, at present, the specific profile of the genes that encode VF closely related to clinical bovine mastitis (Leimbach et al., 2017), as well as the influence of these virulence properties on the severity scores of clinical infections (Suojala et al., 2011), is not fully understood, a fact that represented the major motivation for the present study.

Fimbrial adhesins are well-known bacterial structures that are found on commensal and pathogenic E. coli and are responsible for the adhesion of the pathogen to host cells (Kline et al., 2009). Genes that encode type 1 pili fimH (100\%) and fimA (31.6\%) and Escherichia coli common pilus (ECP) major subunit ecpA (64\%) were prevalent among 114 cows sampled with clinical mammary infections from E. coli. Similar studies involving $E$. coli as a primary agent of bovine mastitis also identified all isolates harboring the gene fimH (Dogan et al., 2006; Fernandes et al., 2011). This finding suggests that as $\mathrm{fimH}$ is a common gene for all $E$. coli, this gene could be used for molecular confirmation of a phenotypic diagnosis of the pathogen (Johnson and Russo, 2002). In addition, high frequencies of fimA and ecpA indicate that the mechanism of adhesion to mammary cells mediated by adhesins may play an important role in the virulence and maintenance of the pathogen in the mammary gland (Tables 1 and 2). Similarly, Ex$\mathrm{PEC}$ isolates infect the urinary tract, where fimbriae reduce the removal of the agent by urine flux (Chahales and Thanassi, 2015).

The bacterial ability to survive in the blood to immune mechanisms of the host has been attributed to 
the presence of polysaccharide capsule, surface proteins, and LPS of the membrane, which produces protection of the pathogen against the action of the complement system (Miajlovic and Smith, 2014). The traT gene of $E$. coli encodes the outer lipoprotein of the membrane that interacts with the complement system, which is considered a serum factor of resistance (Johnson and Stell, 2000). The traT gene has been associated with serum resistance in humans and avian isolates (Nemeth et al., 1991; Mellata, 2013). Studies focusing on the traT gene among $E$. coli isolated from dairy cows with clinical mastitis have reported a prevalence of between 24.6\% (Lehtolainen et al., 2003) and 83.3\% (Dogan et al., 2006). Among dairy cows sampled, a high occurrence of the gene that encodes $\operatorname{traT}(81.6 \%)$ was identified, although the role of the $\operatorname{traT}$ gene as a primary virulence mechanism of $E$. coli in mammary infections is controversial (Nemeth et al., 1991, 1994). The ompT gene, which also encodes serum resistance, was detected at a high frequency (35.1\%) in this study. Like traT, the effect of this gene on the establishment of bovine mammary infections has not been determined.

The majority of bacteria need iron as an essential element for metabolism and multiplication. Low concentrations of this ion among some tissues require that bacteria develop mechanisms of exogenous iron uptake (e.g., siderophores and hemolysins). In the present study, PCR detected $3.5 \%(4 / 114)$ of the isolates with iro $N$ that encodes siderophores and $7 \%(8 / 114)$ with hemolysin $h l y A$. Studies conducted with clinical bovine mastitis by $E$. coli isolated from Finland (Suojala et al., 2011), China (Liu et al., 2014), and Canada (Fairbrother et al., 2015) have described the variable prevalence of the genes related to iron uptake mediated by siderophores, hemolysins, or both. Despite no clear influence on the iron-uptake ability of $E$. coli and bovine clinical mastitis, the presence of siderophores and hemolysins confers additional virulence mechanisms to extra-intestinal infections by the pathogen, such as mammary infections (Kempf et al., 2016).

Invasins are constituted by a thin filament of protein, which involves the bacterial surface and favors the invasion of the host cells (McCulloch and Mamizuca, 2015). Among dairy cows sampled, PCR detected 0.9\% $(1 / 114)$ of the isolates with the gene that encodes invasion, ibe10, although the effect of invasins as a primary $\mathrm{VF}$ of $E$. coli-induced infections in bovine mammary glands is poorly understood.

In this study, most of the isolates $(90.4 \%)$ belonged to phylogroups A and B1 of the E. coli (Clermont et al., 2011), a finding that agrees with similar studies that revealed a predominance of commensal phylogenetic groups of the pathogen isolated from dairy cows with clinical mastitis (Jamali et al., 2018; Tomazi et al., 2018; Guerra et al., 2019).

Despite the investigation of a panel of genes related to ExPEC, the lack of association between gene frequencies and clinical mastitis severity may be due to insufficient statistical power. In addition, clinical signs of the mammary gland may be associated with other genes that have not been investigated or other factors related exclusively to the cow (e.g., immunological status and nutritional conditions peri- and postpartum) may be related to the development of clinical mammary infections (Lehtolainen et al., 2003; Fernandes et al., 2011; Suojala et al., 2011).

Overall, the high in vitro resistance of $E$. coli isolates to various groups of antimicrobials reinforces the emergence of multidrug-resistant gram-negative bacteria from animal and human origin (Cheng et al., 2019). The high frequencies of the genes traT and ompT, related to serum resistance, and ecpA, related to adhesion of the pathogen, in addition to main associations between the genes fim H, ecp $A$, and traT among cows with severity scores of $1(7 / 45=15 \%)$ and $2(14 / 62=22.6 \%)$, indicate that the genes traT, ecpA, and ompT could be further studied as biomarkers of ExPEC among clinical mammary infections of cows. In addition, to our knowledge, the ExPEC genes ompT (serum resistance), ibe10 (invasin), and ecpA (adhesin) were investigated for the first time in cases that were scored for severity.

Further research investigating the virulence mechanisms, phylogroups, and antimicrobial resistance patterns of ExPEC variants is required to better understand the epidemiology and pathogenicity of extraintestinal $E$. coli that affects dairy cows with different severity scores of clinical mastitis.

\section{ACKNOWLEDGMENTS}

This research was supported by the Sao Paulo Research Foundation (FAPESP), grants 2015/19688-8 and 2017/08102-8. The authors declare that there are no conflicts of interest.

\section{REFERENCES}

Bélanger, L., A. Garenaux, J. Harel, M. Boulianne, E. Nadeau, and C. M. Dozois. 2011. Escherichia coli from animal reservoirs as a potential source of human extraintestinal pathogenic E. coli. FEMS Immunol. Med. Microbiol. 62:1-10. https://doi.org/10.1111/j.1574 $-695 X .2011 .00797 . x$.

Chahales, P., and G. Thanassi. 2015. Structure, function, and assembly of adhesive organelles by uropathogenic bacteria. Microbiol. Spectr. 3:1-68. https://doi.org/10.1128/microbiolspec.UTI-0018 -2013 .

Cheng, J., W. Qu, H. W. Barkema, D. B. Nobrega, J. Gao, G. Liu, J. Buck, J. P. Kastelic, H. Sun, and B. Han. 2019. Antimicrobial 
resistance profiles of 5 common bovine mastitis pathogens in large Chinese dairy herds. J. Dairy Sci. 102:2416-2426.

Clermont, O., J. K. Christenson, E. Denamur, and D. M. Gordon. 2013. The Clermont Escherichia coli phylo-typing method revisited: Improvement of specificity and detection of new phylo-groups. Environ. Microbiol. Rep. 5:58-65. https://doi.org/10.1111/1758 $-2229.12019$.

Clermont, O., M. Olier, C. Hoede, L. Diancourt, S. Brisse, M. Keroudean, J. Glodt, B. Picard, E. Oswald, and E. Denamur. 2011. Animal and human pathogenic Escherichia coli strains share common genetic backgrounds. Infect. Genet. Evol. 11:654-662. https:/ /doi.org/10.1016/j.meegid.2011.02.005.

CLSI. 2016. Performance Standards for antimicrobial susceptibility testing. 26th ed. CLSI Supplement M100S. Clinical and Laboratory Standards Institute, Wayne, PA.

Croxen, M. A., R. J. Law, R. Scholz, K. M. Keeney, M. Wlodarska, and B. Finlay. 2013. Recent advances in understanding enteric pathogenic Escherichia coli. Clin. Microbiol. Rev. 26:822-880. https://doi.org/10.1128/CMR.00022-13.

Dogan, B., S. Klaessig, M. Rishniw, R. A. Almeida, S. P. Oliver, K. Simpson, and Y. H. Schukken. 2006. Adherent and invasive Escherichia coli are associated with persistent bovine mastitis. Vet. Microbiol. 116:270-282. https://doi.org/10.1016/j.vetmic.2006.04 .023 .

Fairbrother, J. H., S. Dufour, J. M. Fairbrother, D. Francoz, E. Nadeau, and S. Messier. 2015. Characterization of persistent and transient Escherichia coli isolates recovered from clinical mastitis episodes in dairy cows. Vet. Microbiol. 176:126-133. https://doi .org/10.1016/j.vetmic.2014.12.025.

Farmer, J. J., B. R. Davis, F. W. Hickman-Brenner, A. Whorter, G. P. Huntley-Carter, M. A. Asbury, C. Riddle, H. G. Wathen-Grady, C. Ellias, G. R. Fanning, A. G. Steigerwalt, C. M. O'hara, G. K. Morris, P. B. Shith, and D. J. Brenner. 1985. Biochemical identification of new species and biogroups off Enterobacteriaceae isolated from clinical specimens. J. Clin. Microbiol. 21:46-76.

Fernandes, J. B. C., L. G. Zanardo, N. N. Galvão, I. A. Carvalho, L. A. Nero, and M. A. S. Moreira. 2011. Escherichia coli from clinical mastitis: Serotypes and virulence factors. J. Vet. Diagn. Invest. 23:1146-1152. https://doi.org/10.1177/1040638711425581.

Fuenzalida, M. J., and P. L. Ruegg. 2019. Negatively controlled, randomized clinical trial to evaluate use of intramammary ceftiofur for treatment of nonsevere culture-negative clinical mastits. J. Dairy Sci. 102:3321-3338. https://doi.org/10.3168/jds.2018-15497.

Guerra, S. T., F. M. Dalanezi, C. L. De Paula, R. T. Hernandes, J. C. F. Pantoja, F. J. P. Listoni, H. Langoni, and M. G. Ribeiro. 2019. Putative virulence factors of extra-intestinal Escherichia coli isolated from bovine mastitis with different clinical scores. Lett. Appl. Microbiol. 68:403-408. https://doi.org/10.1111/lam.13113.

Giguère, S., J. F. Prescott, J. D. Baggot, R. D. Walker, and P. M. Dowling. 2010. Terapia antimicrobiana em medicina veterinária [Antimicrobial therapy in veterinary medicine]. Pages 26-42. 4th ed. Roca, Sao Paulo, Brazil.

Hogan, J. S., and K. L. Smith. 2003. Coliform mastitis. Vet. Res. 34:507-519. https://doi.org/10.1051/vetres:2003022.

Hogeveen, H., K. Huijps, and T. J. G. M. Lam. 2011. Economic aspects of mastitis: New developments. N. Z. Vet. J. 59:16-23. https: //doi.org/10.1080/00480169.2011.547165.

IBGE. 2016. Instituto Brasileiro de Geografia e Estatística. Produção da Pecuária Municipal. Ministério do Planejamento, Orçamento e Gestão. v. 42, Rio de Janeiro, Brazil.

Jamali, H., K. Krylova, and M. Aïder. 2018. Identification and frequency of the associated genes with virulence and antibiotic resistance of Escherichia coli isolated from cow's milk presenting mastitis pathology. Anim. Sci. J. 89:1701-1706. https://doi.org/ 10.1111/asj.13093.

Johnson, J. R., and T. A. Russo. 2002. Extraintestinal pathogenic Escherichia coli: "The other bad E coli. J. Lab. Clin. Med. 139:155162. https://doi.org/10.1067/mlc.2002.121550.

Johnson, J. R., and A. Stell. 2000. Extended virulence genotypes of Escherichia coli strains from patients with urosepsis in relation to phylogeny and host compromise. J. Infect. Dis. 181:261-272. https: //doi.org/10.1086/315217.

Kaipainen, T., T. Pohjanvirta, N. Y. Shpigel, A. Shwimmer, S. Pyörälä, and S. Pelkonen. 2002. Virulence factors of Escherichia coli isolated from bovine clinical mastitis. Vet. Microbiol. 85:3746. https://doi.org/10.1016/S0378-1135(01)00483-7.

Kaper, J. B., J. P. Nataro, and H. L. T. Mobley. 2004. Pathogenic Escherichia coli. Nat. Rev. Microbiol. 2:123-140. https://doi.org/ 10.1038/nrmicro818.

Kempf, F., C. Slugocki, S. E. Blum, G. Leitner, and P. Germon. 2016. Genomic comparative study of bovine mastitis Escherichia coli. PLoS One 11:e0147954. https://doi.org/10.1371/journal.pone .0147954 .

Kline, K. A., S. Fälker, S. Dahlberg, S. Normark, and B. HenriquesNormark. 2009. Bacterial adhesins in host-microbe interactions Cell Host Microbe 5:580-592. https://doi.org/10.1016/j.chom 2009.05.011.

Kobori, D., E. C. Rigobelo, C. Macedo, J. M. Marin, and F. A. Avila. 2004. Virulence properties of Shiga toxin-producing Escherichia coli isolated from cases of bovine mastitis in Brazil. Rev. Élev. Méd. Vét. Pays Trop. 57:15-20. https://doi.org/10.19182/remvt .9899 .

Lehtolainen, T., T. Pohjanvirta, S. Pyörälä, and S. Pelkonen. 2003. Association between virulence factors and clinical course of Escherichia coli mastitis. Acta Vet. Scand. 44:203-205. https://doi.org/ 10.1186/1751-0147-44-203.

Leimbach, A., A. Poehlein, J. Vollmers, D. Görlich, R. Daniel, and U. Dobrindt. 2017. No evidence for a bovine mastitis Escherichia coli pathotype. BMC Genomics 18:359. https://doi.org/10.1186/ s12864-017-3739-x.

Lippolis, J. D., B. W. Brunelle, T. A. Reinhardt, R. E. Sacco, B. J. Nonnecke, B. Dogan, K. Simpson, and Y. H. Schukken. 2014. Proteomic analysis reveals protein expression differences in Escherichia coli strains associated with persistent versus transient mastitis. J. Proteomics 108:373-381. https://doi.org/10.1016/j.jprot .2014.06.008.

Liu, Y., G. Liu, W. Liu, Y. Liu, T. Ali, W. Chen, J. Yin, and B. Han. 2014. Phylogenetic group, virulence factors and antimicrobial resistance of Escherichia coli associated with bovine mastitis. Res. Microbiol. 165:273-277. https://doi.org/10.1016/j.resmic.2014.03 .007 .

Marston, H. D., D. M. Dixon, J. M. Knisely, T. N. Palmore, and A. S. Fauci. 2016. Antimicrobial resistance. JAMA 316:1193-1204. https://doi.org/10.1001/jama.2016.11764.

McCulloch. H., and E. M. Mamizuca. 2015. Staphylococcus aureus. Pages 179-188 in Microbiologia. 6th ed. L. R. Trabulsi and F. Alterthum, ed. Atheneu, São Paulo, Brazil.

Mellata, M. 2013. Human and avian extrantestinal pathogenic Escherichia coli: Infections, zoonotic risks, and antibiotic resistance trends. Foodborne Pathog. Dis. 10:916-932. https://doi.org/10 $.1089 /$ fpd.2013.1533.

Miajlovic, H., and S. Smith. 2014. Bacterial self-defence: How Escherichia coli evades serum killing. FEMS Microbiol. Lett. 354:1-9. https://doi.org/10.1111/1574-6968.12419.

Momtaz, H. 2010. Investigation of virulence factors in Escherichia coli isolated from clinical and subclinical bovine mastitis. ScientificWorldJournal 13:122-126.

Momtaz, H., F. S. Dehkordi, T. Taktaz, A. Rezvani, and S. Yarali. 2012. Shiga toxin-producing Escherichia coli isolated from bovine mastitic milk: Serogroups, virulence factors, and antibiotic resistance properties. ScientificWorldJournal 2012:618709. https://doi .org/10.1100/2012/61809.

National Mastitis Council. 1999. Laboratory Handbook on Bovine Mastitis. National Mastitis Council, Madison, WI.

Nemeth, J., C. A. Muckle, and C. L. Gyles. 1994. In vitro comparison of bovine mastitis and fecal Escherichia coli isolates. Vet. Microbiol. 40:231-238. https://doi.org/10.1016/0378-1135(94)90112-0.

Nemeth, J., C. A. Muckle, and R. Y. C. Lo. 1991. Serum resistance and the tra $\mathrm{T}$ gene in bovine mastitis-causing Escherichia coli. Vet. Mi- 
crobiol. 28:343-351. https://doi.org/10.1016/0378-1135(91)90069 $-\mathrm{R}$.

Olde Riekerink, R. G. M., H. W. Barkema, D. F. Kelton, and D. T. Scholl. 2008. Incidence rate of clinical mastitis on Canadian dairy farms. J. Dairy Sci. 91:1366-1377. https://doi.org/10.3168/ jds.2007-0757.

Oliveira, L., and P. L. Ruegg. 2014. Treatments of clinical mastitis occurring in cows on 51 large dairy herds in Wisconsin. J. Dairy Sci. 97:5426-5436. https://doi.org/10.3168/jds.2013-7756.

Partridge, J. D., and R. M. Harshey. 2013. Swarming: Flexible roaming plans. J. Bacteriol. 195:909-918. https://doi.org/10.1128/JB .02063-12.

Pinzón-Sánchez, C., and P. L. Ruegg. 2011. Risk factors associated with short-term post-treatment outcomes of clinical mastitis. J. Dairy Sci. 94:3397-3410. https://doi.org/10.3168/jds.2010-3925.

Pol, M., and P. L. Ruegg. 2007. Treatment practices and quantification of antimicrobial drug usage in conventional and organic dairy farms in Wisconsin. J. Dairy Sci. 90:249-261. https://doi.org/10 .3168/jds.S0022-0302(07)72626-7.

Ribeiro, M. G., R. M. Risseti, C. A. D. Bolaños, K. A. Caffaro, A. B. C. de Morais, G. H. B. Lara, T. O. Zamprogna, A. C. Paes, F. J. P. Listoni, and M. M. J. Franco. 2015. Trueperella pyogenes multispecies infections in domestic animals: A retrospective study of 144 cases (2002 to 2012). Vet. Q. 35:82-87. https://doi.org/10 $.1080 / 01652176.2015 .1022667$.

Srinivasan, V., B. E. Gillespie, M. J. Lewis, L. T. Nguyen, S. I. Headrick, Y. H. Schukken, and S. P. Oliver. 2007. Phenotypic and genotypic antimicrobial resistance patterns of Escherichia coli isolated from dairy cows with mastitis. Vet. Microbiol. 124:319-328. https: //doi.org/10.1016/j.vetmic.2007.04.040.
Suojala, L., T. Pohjanvirta, H. Simojoki, A. Myllyniemi, A. Pitkälä, S. Pelkonen, and S. Pyörälä. 2011. Phylogeny, virulence factors and antimicrobial susceptibility of Escherichia coli isolated in clinical bovine mastitis. Vet. Microbiol. 147:383-388. https://doi.org/10 .1016/j.vetmic.2010.07.011.

Tomazi, T., F. M. Coura, J. L. Gonçalves, M. B. Heinemann, and M. V. Santos. 2018. Antimicrobial susceptibility patterns of Escherichia coli phylogenetic groups isolated from bovine clinical mastitis. J. Dairy Sci. 101:9406-9418. https://doi.org/10.3168/jds.2018 -14485 .

Wenz, J. R., G. M. Barrington, F. B. Garry, R. P. Dinsmore, and R. J. Callan. 2001. Use of systemic disease signs to assess disease severity in dairy cows with acute coliform mastitis. JAVMA 218:567572. https://doi.org/10.2460/javma.2001.218.567.

\section{ORCIDS}

Simony T. Guerra @ https://orcid.org/0000-0002-7557-8427

Henrique Orsi $\odot$ https://orcid.org/0000-0002-6572-913X

Sâmea F. Joaquim ৫ https://orcid.org/0000-0002-5663-9538

Felipe F. Guimarães @ https://orcid.org/0000-0003-3349-7431

Felipe M. Dalanezi ๑ https://orcid.org/0000-0001-8001-4434

Domingos S. Leite @ https://orcid.org/0000-0003-4737-7852

Jose C. F. Pantoja @ https://orcid.org/0000-0002-1648-9360

Vera L. M. Rall ( https://orcid.org/0000-0003-4280-5619

Rodrigo T. Hernandes ๑ https://orcid.org/0000-0001-6695-6003 